\title{
Conjuring Life: Magic in the Poetics of Marina Tsvetaeva
}

\begin{abstract}
Lane Tora, Conjuring Life: Magic in the Poetics of Marina Tsvetaeva. „Poznańskie Studia Slawistyczne” 4. Poznań 2013. Adam Mickiewicz University Press, pp. 239-251. ISBN 978-83-232-2525-6. ISSN 2084-3011.

This article discusses the notion of magic in the poetics of Marina Tsvetaeva (1892-1941) against the backdrop of romanticism and Russian modernism. Magic is related to the poet's explorations of folklore, and also to Romantic, symbolist and futurist invocations of it. Concepts of magic are central to Tsvetaeva's poetics; she considers conjuration to be a property of language that facilitates contact with the demonic, elemental and natural aspects of the world. These elemental aspects are not to be considered merely as the poet's mythologisations of the world, but also as her reflections on the capacity of poetic language to speak of what is otherwise hidden in the world.
\end{abstract}

Keywords: Tsvetaeva, magic, conjuration, romanticism, modernism, poetry, the Sublime

\section{Introduction}

The notion of magic represents a highly influential tenet in Russian modernism, which involves several complex questions surrounding the technique of writing poetry and the nature of poetic language. This interest in magic is related to the legacy of the German Romantic tradition and its insistence that the poetic word carries an organic force. In his sixth „logological” fragment, Novalis writes: „Every word is a word of conjuration. The spirit it calls will appear" (,Jedes Wort ist ein Wort der Beschwörung. Welcher Geist ruft - ein solcher erscheint") ${ }^{1}$. Novalis' formulation represents a poetological reflection on the nature of poetic language.

${ }^{1}$ F. von Hardenberg (Novalis), Schriften. Zweiter Band, Das philosophische Werk, ed. R. Samuel, H.J. Mähl, G. Schulz, Stuttgart 1960, p. 523. 
He insists in an absolute way that every word conjures. The poet thereby invokes an image of the magic of language as the conjurational force of its inherent literal meanings. The magic of language can thus be formulated as the ability to conjure an elemental presence. The fragment leaves unanswered what this literal meaning is, but the question for Novalis and many writers of his and later times was how to grasp and attain this language in poetry and consequently how to enter into a living relationship with the elemental in the world in and through poetry.

In Russian symbolism and post-symbolism, there was a general interest in animism, mysticism and folklore ${ }^{2}$; besides Bely, Balmont, Blok, Repin and Vrubel, one can also mention, amongst others, such modernists as Stravinsky, Kandinsky and Khlebnikov. One writer who was deeply affected by notions of magic and elemental forces in her understanding of poetry was Marina Tsvetaeva. For her, as for many other Russian modernists, folk art represented a way to revive the sacred aspects of art. Inspired by the Romantics and the Russian symbolists, she explored folk poetry with regards to language and performance for the sake of grasping the notion of the magic power of the word to conjure the elemental. She explored folk art in an unprecedented way, but the kinship between her writings and folk art is not to be characterized in terms of identity, as both Zubova and Faryno do ${ }^{3}$. Tsvetaeva's explorations of folk art show a Romantic strain, in that she seeks in folk art a means to speak and enter into contact with the hidden presence of the elemental, which she interprets as an uncanny manifestation in line with the aesthetic category of the sublime (das Erhabene), central to German romanticism. The elemental is not a transcendental category, but life in a more intense form.

${ }^{2}$ This interest is not solely linked, of course, to the influence of Novalis, but should also be related to the impact of romanticism on Russian modernism. For an analysis of Novalis' impact on Vyacheslav Ivanov, see, for instance, M. Wachtel, Russian Symbolism and Literary Tradition, Wisconsin 1995.

${ }^{3}$ Both L. Zubova, in several works (for instance Iazyk poezii Mariny Tsvetaevoi, 1999), and J. Faryno, Mifologizm i teologizm Tsvetaevoi („Magdalina” - „Tsar'-Devitsa” „Pereulochki”), Wien 1985, have analyzed Tsvetaeva's excursions into folk art in greater depth, but both fail to relate them to literary tradition. I discuss this in greater depth in Rendering the Sublime. A reading of Marina Tsvetaeva's fairy-tale poem The Swain, Stockholm 2009, p. 15-17. 
In this article, I will provide a survey of the notion of magic in Tsvetaeva's poetics against the background of Russian modernism and romanticism, concentrating primarily on her essayistic writings, which contain reflections on poetry that can give us vital clues to her poetry. I will show that Tsvetaeva's understanding of the magic of poetry was always closely related to a Romantic fairy-tale experience of life, but that her experiments with an elemental magic at the start of her literary career were more inspired by the symbolists' writings, whereas in her mature writings she came very close to Novalis' understanding, in exploring folk poetry to find a language that was literal and pre-rational, able to invoke or conjure life in an elemental, and at the same time fuller, more sublime, presence.

\section{Folk art in the poetry of Tsvetaeva}

In Tsvetaeva's first two collections of poems, the latter of which is significantly called The Magic Lantern (Vol'shebnyi Fonar'), we find ourselves in a Romantic landscape of mystical forests and lunar light, with a ,magic house”, witches, magicians and fairy tales. Another telling example of her interest in magic is the longer poem The Magician (Charodei), from 1914. In the early poetry, her attraction to folk art was felt mostly in the imagery, but over the course of several formative years, 1916-1923, Tsvetaeva explored the technique of folk poetry with regard to language, rhythms and a kind of performative writing, as opposed to the expression of a subject. She developed a unique folkloric style, which reached its climax in a series of narrative poems written in the early 1920s, Side Streets (Pereulochki, 1922), and in her long poetic tales, written in the subgenre of poema-skazka ${ }^{4}$ : The Tsar-Maiden (Tsar'-Devitsa, 1920) and The Swain (Mólodets, 1924) ${ }^{5}$. The Swain was to be the last in this series of poems based on models of Russian folk art, apart from an unfinished poem called Egorushka, which Tsvetaeva began in 1921 and attempted to return to in 1923 and 1928. In the genre of the poetic tale, it was followed only by

\footnotetext{
4 The poema-skazka developed as a sub-genre and an equivalent to the German Kunstballade in Russian Romantic poetry. Examples include the fairy tales of Pushkin.

${ }^{5}$ I offer an in-depth analysis of her poetic style in the fairy-tale poem Molodets in Rendering the Sublime.
} 
the The Pied Piper (Krysolov, 1925), inspired by the German legend and literary treatments of it in German romanticism and after. After she emigrated from Soviet Russia to Europe, in 1922, Tsvetaeva came to gradually abandon the Russian folkloric style, but her work with folk art continued to be felt in her poetic language and themes.

\section{Symbolist elemental demonology}

The attraction to magic, folk art, mysticism and animism was common to all Russian symbolists, but so-called „younger” (mladshie), secondgeneration poets such as Vyacheslav Ivanov, Alexander Blok and Andrei Bely developed this interest further. Like their Romantic predecessors, they construed a genealogy of literature, according to which the origins of true poetry are to be found in folk poetry ${ }^{6}$. Blok asserted in the essay The poetry of spells and conjurations (Poeziia zagovorov $i$ zaklinanij, 1908) that the ,gold of genuine poetry" (,zoloto nepoddelnoi poezii") was to be found in spells, folk magic and folk rituals ${ }^{7}$. What particularly interested the younger symbolists in folk poetry was the idea that the word there stands in an organic relationship to the world, which has become lost in modern poetry.

Magic went hand in hand with the symbolists' myth-creating and lifecreating project, because in their view it offered a means of overcoming the distinction not only between subject and object, but also between life and poetry. Blok argued that folk poetry was a poetry where ,word and action are inseparable", and Bely asserted in similar terms in The Magic of Words (Magiia slov, 1910) that the poetic word had the power to conjure, which he interprets in terms of exerting influence ${ }^{8}$. The basis for the fusion of

\footnotetext{
${ }^{6}$ The German pre-Romantics, such as Goethe, the Brothers Grimm and Herder, turned to the world of folklore to find, as Herder writes, the people's voice and Naturpoesie, and in Russian literature they were followed most notably by Pushkin and Zhukovsky, who in forging a national literature took a strong interest in the mythical world of folklore and fairy tales.

${ }^{7}$ A. Blok, Poeziia zagovorov i zaklinanij, in: Sobranie sochinenij v voz'mi tomakh, ed. V.N. Orlov, A.A. Surkov, K.I. Chukovskii, t. 5, Moskva-Leningrad 1962, p. 36.

${ }^{8}$ A. Bely, Magiia slov, in Kritika. Estetika. Teoriia Simvolizma v dvukh tomakh, t. 1, Moskva 1994.
} 
word and action was a cosmogony of elemental or natural forces (stikhiia). Blok asserts that the word becomes act in magic, while both word and act are elements, behind which there is always ,the element of the dark will” (,stikhiia temnoi voli”) ${ }^{9}$. As I will demonstrate below, this last assertion is particularly interesting in relation to Tsvetaeva, who also saw a demonic presence in the magic of the word. In Art in the Light of Conscience, she speaks of „the Demon (the element)" („Demon [stikhiia]”) that takes possession of the poet. Moreover, the demonic is a recurrent and dominant theme in several late autobiographical essays, most notably in The Devil $(\text { Chert })^{10}$.

Although Tsvetaeva never mentions the essays of Blok and Bely in her writings, their basic assumptions are undoubtedly central to her poetics and her understanding of the power of the word, both in her youth and in her mature writings. Like the Russian symbolists, she also tended to fuse poetry and life, word and act, and she explored the magic of the word in life as well as in poetry to exert influence. An eyewitness, Vera Zviagintseva, recalls how Tsvetaeva attempted to enchant a man by means of magic words ${ }^{11}$. Another example of how ideas of elements and magic came to affect her is a letter to Konstantin Rodzevich, where she writes that she is an elemental spirit:

Родзевич, я скажу Вам тайну, только не смейтесь я - Elementargeist, стихийное существо: саламандра или ундина, у меня нет души, душа (по всем сказкам) таким существам дается через любовь ${ }^{12}$.

9 ,(...) слово становится делом, обе стихии равноценны, могут заменять друг друга; за магическим действом и за магическим словом - одинаково лежит стихия темной воли". А.A. Blok, op. cit., p. 48

${ }^{10}$ See, for instance, S. Elnitskaya, Tsvetaeva $i$ Chert, „Russian Language Journal” vol. XL, no. 136-138, 1986, p. 75-93.

11 „Когда я ночью вошла за спичками, они уже лежали «в позиции». Она лежала на нем и завораживала словами. (...) Она часто говорила, что главная ее страсть собеседничество. А физические романы необходимы, потому что только так проникаешь человеку в душу". V. Schweitzer, Stranitsy k biografii Mariny Tsvetaevoi, „Russian Literature” no. 60, 1981, p. 323-356.

${ }^{12}$ M. Tsvetaeva, Neizdannoe: Zapisnye knizhki, ed. E.B. Korkina, M.G. Krutikova, Moskva 2000, s. 309. See also an analysis of this quote and Tsvetaeva as Elementargeist by R.S. Voitekhovich, Tsvetaeva kak Elementargeist, in: Chuzhbina, rodina moia. Emigrantskii period zhizni Mariny Tsvetaevoi. XI Mezhdunarodnaia konferentsiia. Sbornik dokladov, ed. I.Iu. Beliakov, Moskva 2004, p. 366-388. 
[Rodzevich, I want to tell you a secret, but don't laugh. I am... an Elementargeist, an elemental being, a Salamandra or an Undine. I have no soul, because (according to all tales) a soul is only given to such beings through love - transl. T.L.]

Here she expresses an idea of herself as a medium and the element of being Salamandra, which is fire, and fire is also the most common element that she identifies her poetic pen with in her poetry ${ }^{13}$. This kind of straightforward identification with a mythological or metaphysical Elementargeist is, however, rarely to be found in her poetry, where she instead explores the appearance in language of natural elements as hidden presences ${ }^{14}$. A much later example can be found in the essay The living on the living (Zhivoe o zhivom, 1933), which is about the poet Maksimilian Voloshin. In it, Tsvetaeva reflects on the notion of myth-creating in symbolism and recounts a situation from her youth in which Voloshin stopped or extinguished ,,a fire with words” (,Pozhar byl ostanovlen - slovom”) ${ }^{15}$.

Although the symbolists, with their fusion of life and poetry based on an animistic and elemental concept of the word, made a profound impact on Tsvetaeva, she came to differ radically in the way that she explored this magic. Tsvetaeva did not discuss magic in the kind of scientific-historic discursive manner that Blok, Bely and later Khlebnikov employed, and neither did she use technical terms from magic when describing or giving names to her poems. Central to Tsvetaeva's interest in magic is instead the elemental, the forms in which it appears and the means of bringing it out in poetry. Her language is almost exclusively poetological, because, for Tsvetaeva, magic cannot be separated as a form of rhetoric, discourse or act; it is what is always at stake in poetic language. More so if the symbolists tended to fuse life and poetry in a rather theatrical or dramatic manner, turning poetry into the scene of life, as well as life into the scene of poetry.

\footnotetext{
${ }^{13}$ See for instance The Swain, The Tsar-Maiden, The Poem of the Staircase (Poema Lestnitsa, 1926) and the notion of the devil in The Devil (Chert).

${ }^{14}$ When she treats the elemental in her poetry, it is always as a poetic presence or manifestation, as, for instance, in the case of the demonic swain in the fairy-tale poem The Swain, who appears as a young man to everyone, but to the main protagonist Marusia also in the element of fire.

${ }^{15}$ M. Tsvetaeva, Izbrannaia proza v dvukh tomakh 1917-1937, ed. A. Sumerkin, t. 2, New York 1979, p. 65.
} 
Tsvetaeva came to oppose ordinary life with literature, as the locus of the elements and of life in its fuller form, and she explored poetic language in its power to conjure life in its sublimity ${ }^{16}$.

\section{Romantic folklore and the fairy tale}

In order to understand Tsvetaeva's attraction to folk art and its notions of magic, it is crucial to understand her attraction to the world of fairy tales. Her readings of them were deeply imbued by the Romantic tradition: in such tales, she found traces of a fuller, more sublime world of elemental presences ${ }^{17}$. In her autobiographic writings, Tsvetaeva again and again construes the genealogy of her poetic awareness in relation to the experience of the fairy-tale folkloric world of Romantic literature. Her poetry, and indeed - according to her autobiographic writings - her entire world, was from the beginning immersed in a world of Romantic and lateRomantic literature, populated with lyrical and folkloric figures, or ,with Undines, Jane-Eyres and Anton Goremyks", as she writes in the essay Mother and Music (Mat' i muzyka, 1935) ${ }^{18}$. Central to that essay is the question of why she became a poet, when her mother steered her towards the piano, and she answers the question in terms of spells, charms and possession. The spell exerted by literature was greater than that of music ${ }^{19}$.

\footnotetext{
${ }^{16}$ In an essay on the artist Natalia Goncharova, she asks the question: „Does the artist have an individual biography?” („Est' li u khudozhnika lichnaia biografiia?”) and answers: „The canvas: I am. What precedes it is only the way to the canvas” (,Kholst: esm'. Predydushchee tol'ko khod k kholstu'). The poet uses the Church Slavonic word esm' (I am) for the first person singular of byt' (to be) in order to convey that the canvas itself asserts that it is, and that it does so in a more absolute form of being. M. Tsvetaeva, Sobranie sochinenij $v$ semi tomakh, ed. A. Saakiants and L. Mnukhin, t. 4, Moskva 1994, p. 78-79.

${ }^{17}$ In the loci of the German Romantic fairy tale and ballad, the Kunstmärchen and Kunstballade, and in parallels in Russian romanticism, Tsvetaeva sensed a figure for a horrifying poetic presence, reminiscent of the uncanny presence of the aesthetic category of the Sublime (das Erhabene). She develops this idea in particular in the essay Dva Lesnykh Tsaria. M. Tsvetaeva, Izbrannaia proza v dvukh tomakh 1917-1937, ed. A. Sumerkin, New York 1979, p. 314-318.

${ }^{18}$ M. Tsvetaeva, Mat' i muzyka, Letchworth 1977, p. 175.

${ }^{19}$ Tsvetaeva insists that one ought not to explain the world to a child, but cast a spell on the child, by means of obscure words: „Разъяснять ребенку ничего не нужно, ребенка
} 
In that world, her mother infused in her and her sister a sense of kinship with the literary characters as something both present and absent in the world:

Как уплотняла нас невидимостями и невесомостями, этим навсегда вытесняя из нас всю весомость и видимость. И какое счастье, что все это было не наука, а Лирика, - то, чего всегда мало, дважды - мало: как мало голодному всего в мире хлеба, и в мире мало - как радия, то, что само есть - недохват всего, сам недохват, только потому и хватающий звезды! - то, чего не может быть слишком, потому что оно - само слишком, весь излишек тоски и силы, излишек силы, идущий в тоску, горами двигающую 20 .

[How she filled us up with invisible and insubstantial things, once and for all expulsing everything visible and substantial within us. How lucky we were that it wasn't science, but Poetry, which there is always too little of - in two ways. First, because for the starving there is always too little bread in the world, and second, it is something too small for the world - like radium, that which in itself cannot comprise everything, is deficiency itself, and only for that reason touching the stars! - a deficiency of which there cannot be too much, because it is too much itself, all the excess of grief and force, the excess of a force on its way to grief, which is able to move mountains - transl. T.L.]

Mother and Music represents an interpretation of the childhood experience of the already mature poet in charge of her poetics, and it should be read as a metapoetic comment on Tsvetaeva's view on the force of poetry, and in particular in relation to the fairy-tale world of Romantic literature $^{21}$. Tsvetaeva's mother paradoxically filled Marina and her sister up, or „sealed them in" (,uplotniala"), with ,the invisible and insubstantial” (,nevidimostiami i nevesomostiami"), which destined them to a life in Poetry. The visible and substantial - in other words, concrete things - was ousted from their world or field of experience and replaced by things that barely exist in the world of lyrical poetry. Tsvetaeva and her sister were

нужно - заклясть. И чем темнее слова заклятия - тем глубже они в ребенка врастают, тем непреложнее в нем действуют: «Отче наш, иже еси на небесех...»”. Ibidem, p. 173. The essay ends with the assertion that: „There are forces that even a mother cannot master” (,Есть силы, которых не может даже в таком ребенке осилить даже такая мать”). In other words, literature was a stronger force than her mother's will to make her a pianist.

${ }^{20}$ Ibidem, p. 175.

${ }^{21}$ See also Karin Grelz's analysis of Mat'i muzyka, in: Beyond the Noise of Time. Readings of Marina Tsvetaeva's Memories of Childhood, Stockholm 2004. 
doomed to „something of which there is always too little" (,to, chego vsegda malo"), because ,you never have enough of it" (,to, chego ne mozhet byt' slishkom”). There is too little of it, exactly because it is „excess in itself" (,samo slishkom"), for which there is no place on earth, with its delimitations.

In Tsvetaeva's interpretation of this immense force that destined her for a life in poetry from her childhood on, there is a parallel to the elemental presences that the poetic world conjures, according to Novalis' sixth logological fragment. As for Novalis, language, or, more precisely, poetry, is the mediator to a world of elemental presences. For Tsvetaeva, lyrical poetry is the locus of hidden presences in the world, and they are hidden because they are too great to be housed anywhere else than in the form of poetry or literature. As I will show, the magic of poetry was for Tsvetaeva the power to conjure this immense or sublime presence, and she approached both those presences and language as elemental forces.

\section{An elemental poetics}

Tsvetaeva's interest in magic came to be directed towards the forms of appearance of elemental life, or the means of conjuring it, in poetry. She developed an entire elemental and demonological poetics in both her poetic and her essayistic writings. The most telling formulation of this poetics is to be found in Art in the Light of Conscience (Iskusstvo pri svete sovesti, 1932), which belongs to a series of essays, concluding, as Irina Shevelenko writes, Tsvetaeva's philosophical reflections about art and the artist ${ }^{22}$. A key argument in the essay is that art must not take conscience into consideration, while the artist in the process of writing is subject to „the inspiration of natural forces" (,naitiie stikhii”) acting upon him or her. The poet is possessed by art, because art is an instrument of the elements:

Когда я говорю об одержимости людей искусства, я вовсе не говорю об одержимости их искусством. Искусство есть то, через что стихия держит и одерживает; средство держания (нас - стихиями) $)^{23}$.

${ }^{22}$ I.D. Shevelenko, Literaturnyi put' Tsvetaevoi: Ideologiia - poetika - identichnost' avtora v kontekste epokhi, Moskva 2002, p. 402-403.

${ }^{23}$ M. Tsvetaeva, Izbrannaia proza..., p. 401. 
[When I speak of the possessed condition of people of art, I certainly don't mean they are possessed by art. Art is that through which the elemental force holds - and overpowers: a means for the holding (of us - by the elements) transl. T.L.]

Tsvetaeva insists that art is not capable of taking possession of people in itself; it can only do so because it is the locus of elemental forces. Art is „the means" (,sredstvo") by which we feel and come under the influence of the elemental forces, and so we can understand the essence of art as the appearance of the elemental. Tsvetaeva's concept of elemental forces shows a certain kinship with Blok's understanding of them in „Poeziia zagovorov i zaklinanij”, as ,the element of the dark will” (,stikhiia temnoi voli"). She understands them as forces of nature, acting in a demonic way on man. As already mentioned, the element is equated to a demon, portrayed as some force, acting in and upon the poet, as nature. It is not necessarily evil; its most important quality is that it leads the poet to bring out nature and ,things" (,,veshchi”) in some language beyond the categories of conscience $^{24}$ :

Искусство есть та же природа. Не ищите в нем других законов, кроме собственных (не самоволия художника, не существующего, а именно законов искусства). Может быть - искусство есть только ответвление природы (вид ее творчества). Достоверно: произведение искусства есть произведение природы, такое же рожденное, а не сотворенное ${ }^{25}$.

${ }^{24}$ And further: „Достоверно: произведение искусства есть произведение природы, такое же рожденное, а не сотворенное. (А вся работа по осуществлению? Но земля тоже работает, французское «la terre en travail». А само рождение - не работа? O женском вынашивании и вынашивании художником своей вещи слишком часто упоминалось, чтобы на нем настаивать: все знают - и все верно знают.) В чем же отличие художественного произведения от произведения природы, поэмы от дерева? Ни в чем. Какими путями труда и чуда, но оно есть. Есмь! Значит, художник - земля, рождающая, и рождающая все. Во славу Божью? А пауки? (есть и в произведениях искусства). Не знаю, во славу чью, и думаю, что здесь вопрос не славы, а силы. Свята ли природа? Нет. Грешна ли? Нет. Но если произведение искусства тоже произведение природы, почему же мы с поэмы спрашиваем, а с дерева - нет, в крайнем случае пожалеем - растет криво”. Ibidem, p. 381.

${ }^{25}$ M. Tsvetaeva, Art in the Light of Conscience. Eight Essays on Poetry by Marina Tsvetaeva, transl. A. Livingstone, Bristol 1992, p. 149. 
[Art is the same as nature. Don't seek in it other laws than its own (don't look for the self-will of the artist, which isn't there - only look for the laws of art). Perhaps art is just an offshoot of nature (a species of its creation). What is certain is that a work of art is a work of nature, just as much born, and not made - transl. T.L.]

According to the poet, the artist does not create, but gives life to art, just as nature gives life. Nature and elements work in the artist in the process of creation. Tsvetaeva argues, for instance, that when Pushkin wrote parts of A Feast in Time of Plague (Pir vo vremia chumy), it was not with words, but with ,the tongues of flame, in ocean waves and desert sands"26 (,iazykami plameni, valami okeana, peskami pustyni”) ${ }^{27}$. The elemental can thus also be understood as life in its natural form, beyond the categories of conscience, and art as the locus of the appearance of this elemental life. Language, or rather ,the word” (,slovo”), is the ,element of all elements" (,stikhiia stikhii") ${ }^{28}$, as she asserts in the essay.

In a similar way to Novalis, Tsvetaeva considers in her mature writtings the appearance of the elemental not as the result of the writer's conscious performance of magic, but as the act of bringing out, listening to and fathoming those presences in poetic language. Whatever is to be brought out in art is something that is beyond or contrary to the conscious will and understanding of the poet. This something is, in Tsvetaeva's terms, coming to being through the author: „I must create, that is, name, the one who called me" (,Ia dolzhen togo, kto menia zval sozdat', to est', nazvat" $)^{29}$. The poet is called by someone, or something, understood as elemental, but the element is rather something in the world speaking to the poet in its elemental other form, that is, in a form that is not yet known, and often contrary to the known. The poet must create, or rather bring out, this ,thing” (,veshch”), and poetic expression is the naming of the thing, which is in possession of the poet. Tsvetaeva therefore calls the poetic process a ,hearing lesson" (,slukhovoi urok") ${ }^{30}$, during which the poet learns the right expressions to bring out a phenomenon in words. In other words, the poetic process is conceived of as a form of conjuration or invo-

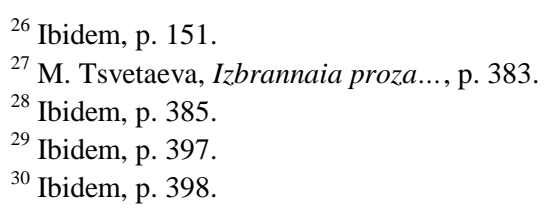


cation, but not of a spirit that the poet in a conscious act wishes to call upon as a sorceress, but by „listening out” the elemental nature that is present in language.

\section{The ,literal word" and the element}

The elemental word is connected to a notion of literal meaning, demonically hidden in language just as nature is hidden in man. In the Poetry of Intent that she sketched in several diary entries in 1924, she puts forward the notion of a secret writing of demonic malevolent ,intent" (,umysel”). She advocates a particular kind of „secret writing” (,tainopis”) to render this demonic intent: „In the literal (pre-lingual) world, intents are the same as secret writing in this world” („Umysly - v mire doslovnom (doslovesnom) to zhe, chto tainopis v mire sem") ${ }^{31}$. The poet thus suggests, with a pun on the prefix $d o$ - (pre), that it is paradoxically only the prelingual (doslovesnoe) that has literal (doslovnoe) meaning, and further that this pre-lingual literal can be rendered only in secret writing. Tsvetaeva sketches a world of natural elements present to us in a hidden form in „this" world, and in order to bring it out in its hidden forms of appearance the poet must write in a secret language.

It is regrettably not within the scope of this article to present examples of how Tsvetaeva sought to bring out this magic in her writing, but only to draw some general lines to characterize her writing. Just as Tsvetaeva's notion of secret presences in the world and in language was closely related to otherworldly presences in the fairy tale, the notion of a secret writing is paralleled in folkloric language by secret language or speech (tainyi iazyk; tainaia rech'), which was employed to avoid naming hidden forces in nature $^{32}$. Liudmila Zubova has analysed the linguistic aspects of Tsvetaeva's folkloric experiments, and she singles out syncretism, stem repetition and

${ }^{31}$ M. Tsvetaeva, Neizdannoe. Svodnye tetradi, eds E.B. Korkina, I.D. Shevelenko, Moskva 1997, p. 298.

${ }^{32}$ I expand on the relationship between the concept of secret writing and folk poetry in more depth in my dissertation. T. Lane, Rendering the Sublime. A reading of Marina Tsvetaeva's fairy tale poem The Swain, Stockholm 2009. 
word transformation as means of generating greater semantic variety ${ }^{33}$. The poet plays, however, with folkloric taboos primarily to avoid conventional naming and to reach for that hidden literal level of language that can bring out or conjure the hidden elemental of the world. Folk poetry becomes a crucial impulse to the paronomastic games that Karlinsky saw as an integral part of Tsvetaeva's language ${ }^{34}$, and it provided the poet as well with a different animistic reference, as a supple metaphorical gamma to bring out that other „literal” language. This world is characterized by „too much", or life beyond rational forms of representations, given to us, as Tsvetaeva understands, in poetic language when it is language in its elemental nature.

\section{Conclusion}

Marina Tsvetaeva's interpretation of and treatment of magic in art is close to Novalis' formula: „Every word is as a word of conjuration. The spirit it calls will appear" (,Jedes Wort ist ein Wort der Beschwörung. Welcher Geist ruft - ein solcher erscheint"). Folk art attracted her primarily as a question not of how to perform magic through poetry, but how to hear and fathom the magic inherent in ,literal" language. Central to her understanding of the creative act is the notion of subordination, of being struck and possessed. What is to be conjured in the magic of poetic language is what is already present, but neglected, in the world of human categories or representation. This is considered a mythical world that is demonic and elemental, and it is to be attained through mythological, demonic and elemental language. To attain this, the poet must listen to the ways that the elemental or living speaks in a hidden way in the world and in language.

${ }^{33}$ L.V. Zubova, O iazyke fol'klornykh poem M. Tsvetaevoi „Tsar'-Devitsa” (1920 g.), „Pereulochki” (1922 g.), Stockholm 1996, p. 5.

${ }^{34}$ S. Karlinsky, Marina Tsvetaeva. Her Life and Art, Berkeley 1966, p. 149. 
